\title{
Synthesis, characterization and superoxide dismutase activity of bi-copper(II)-bisacetato- $\mu$-phthalicacid[bis(benzyloxy)ethyl]ester
}

\author{
BABITA SARMA $^{\mathrm{a}}$, PRADIP K BHATTACHARYYA ${ }^{\mathrm{b}}$ and DIGANTA KUMAR DAS ${ }^{\mathrm{a}, *}$ \\ a Department of Chemistry, Gauhati University, Guwahati, Assam, India 781014 \\ ${ }^{b}$ Department of Chemistry, Arya Vidyapeeth College, Guwahati, Assam, India 781016 \\ e-mail: digantakdas@gmail.com
}

MS received 10 February 2014; revised 6 August 2014; accepted 19 August 2014

\begin{abstract}
A new binuclear copper(II) complex, bridged by the ligand phthalicacid[bis(benzyloxy)ethyl]ester, where each copper(II) is coordinated to one carboxylate (from ligand) and one acetate in square planar mode is reported. The ligand synthesized by the reaction of phthalic anhydride and ethylene glycol, has been characterized by FT-IR, ${ }^{1}$ HNMR and LCMS. The binuclear Copper(II) complex has been characterized by UV/visible spectra, FTIR spectra, EPR spectra, ESI-MS spectra, magnetic moment measurement and thermogravimetric analysis. DFT calculation has shown a $\mathbf{Z}$ type structure for the complex. Excellent superoxide dismutase activity with $\mathrm{IC}_{50}$ value $8.6 \times 10^{-6} \mathrm{M}$ for the complex has been observed.
\end{abstract}

Keywords. phthalic anhydride; ethylene glycol; acetate; copper(II); superoxide; IC I0 $_{50}$ DFT.

\section{Introduction}

Copper(II) is a biologically important metal ion involved in a number of enzymes such as - superoxide dismutase (SOD), tryosinase, galactose oxidase, B - hydroxylases, monoaminooxidase, ascorbic acid oxidase, plastocyanine, azurine, etc. ${ }^{1-3}$ Complexes of copper in oxidation state +2 are also biologically significant because of their antioxidant and free radical scavenging activity. ${ }^{4,5}$ Binuclear copper (II) complexes are potential models for a number of important biological systems containing couple sites ${ }^{6}$ and have been studied extensively. ${ }^{7-12}$ Besides, copper (II) complexes of multidentate Schiff base ligands have played a vital role in the development of coordination chemistry. ${ }^{13-15}$ The bimetallic copper (II) complexes have also attracted much attention in magneto chemistry due to the spinspin interaction between the copper (II) centres.

SOD is an enzyme involved in protecting biological cells from the toxic effects of superoxides. ${ }^{16}$ Based on the metal ions present in the active sites, SODs have been divided into - $\mathrm{Cu}-\mathrm{Zn}-\mathrm{SOD}, \mathrm{Mn}-\mathrm{SOD}$ and Fe-SOD, out of which the first one is found in mammals. ${ }^{17}$ Deficient level of SOD concentration in human body is one of the reasons behind diseases and disorders like diabetes, ischemia, cataract, Parkinson's disease, cancer, etc. ${ }^{18,19}$ Supplementation of antioxidant enzymes should be a part of the treatment but administration of

${ }^{*}$ For correspondence these enzymes through oral or intraperitonial routes is severely restricted due to their rapid degradation and short life time in biological systems. ${ }^{20}$ Small metal complexes having good superoxide scavenging activity are potential candidates in this regard.

Copper(II) complexes with Schiff base ligands derived from various aldehydes and ketones have been reported to mimic SOD activity. ${ }^{21}$ Other examples in this regard include imidazole bridged copper(II) complexes, ${ }^{22}$ planar copper(II) complex on addition of a base such as $\mathrm{N}$-methyl imidazole or pyridine, ${ }^{23}$ curcumin complexes of copper(II), ${ }^{24}$ etc. There is also a report that the copper(II) complexes with Schiff base ligands of salicylaldehyde semicarbazone has SOD activity which could be tuned by heterocyclic bases, pyridine and $\mathrm{N}$-methyl imidazole. ${ }^{25}$

In present day, density functional theory (DFT) has become an effective tool for determining structure, electronic properties of molecules, vibrational frequencies, atomization energies, ionization energies, etc. ${ }^{26-29}$ Particularly when X-ray grade crystals are not obtained, DFT calculation has been an effective mode of confirming the structure of metal complexes.

In this paper, we report the synthesis of a new ligand phthalicacid[bis(benzyloxy)ethyl]ester characterized by FTIR, ${ }^{1}$ HNMR and mass spectra. This ligand has been reported to bridge two Copper (II) ions through its two carboxylates and each Copper (II) is coordinated to one acetate in square planar fashion. DFT calculation shows a $\mathrm{Z}$ type structure for the 
complex. The high superoxide scavenging activity of the complex is also reported.

\section{Experimental}

\subsection{Materials and methods}

Phthalic anhydride and ethylene glycol were purchased from Merck and copper(II)acetate monohydrate was purchased from LOBA Chemie. The FTIR spectra were recorded in $\mathrm{KBr}$ discs on a Perkin Elmer spectrum RXI FTIR system. The ${ }^{1} \mathrm{H}$ NMR spectra were recorded in Bruker Ultra shield 300 spectrophotometer. The electronic spectra in the range of 200-1000 $\mathrm{nm}$ were obtained in acetonitrile on a UV-1800 SHIMADZU spectrophotometer. Thermogravimetric measurements were carried out on a PERKIN ELMER 300 TGA instrument. CHI 600B Electrochemical Analyzer (USA) with a three electrode cell assembly was used for electrochemical studies. The electrodes were cleaned as per reported procedure. ${ }^{30}$ Electron paramagnetic resonance (EPR) spectra were recorded on a Bruker EMX spectrometer (centre field $0.4 \mathrm{~T}$, sweep width $0.8 \mathrm{~T}$, resolution 1024 points, microwave frequency $9.877 \times 109$ $\mathrm{Hz}$, power $0.188 \mathrm{~mW}$ ). Magnetic susceptibility measurements were performed at ambient temperature by the Gouy method using a Cambridge magnetic balance (UK), LC-MS data were recorded in Agilent LCMS 6410 Series (USA).

\subsection{Synthesis and characterization of phthalic acid bis(benzyloxy)ethyl ester $\left(L, \mathrm{C}_{18} \mathrm{H}_{14} \mathrm{O}_{\mathbf{8}}\right)$}

$20 \mathrm{mmol}(2.96 \mathrm{~g})$ phthalic anhydride was taken in a mortar and grinded. $10 \mathrm{mmol}(0.6 \mathrm{~mL})$ of ethylene glycol was added dropwise with constant stirring. The reaction mixture was heated to $60^{\circ} \mathrm{C}$ and 2-3 drops of pyridine was added. The mixture was cooled to obtain an off-white product which was then recrystallized from methanol. The synthetic path for the ligand (L) is shown in scheme 1 below.

FTIR $\left(\mathrm{KBr}\right.$ pellet, $\left.\mathrm{cm}^{-1}\right): 3404\left(v_{\mathrm{O}-\mathrm{H}}\right), 2920.7$ $\left(v_{\mathrm{C}-\mathrm{H}}\right), 1627\left(v_{\mathrm{C}=\mathrm{O}}\right), 1289.4\left(v_{\mathrm{C}-\mathrm{O}}\right), 1391.3\left(\delta_{-\mathrm{CH} 2-}\right)$, 756 and 705 (aromatic $\mathrm{C}-\mathrm{H}$ out of plane bending).

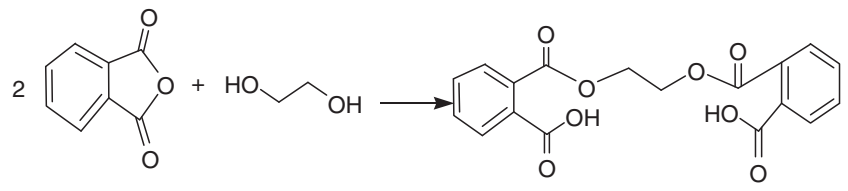

Scheme 1. Synthetic path for the ligand $(\mathbf{L})$.
LCMS: $\mathrm{m} / \mathrm{e}\left(\mathrm{M}^{+}\right)$357.3, calc. 358.3. ${ }^{1} \mathrm{HNMR}\left(\mathrm{CDCl}_{3}\right.$, $\delta$ in ppm): $7.72(2 \mathrm{H}, \mathrm{t}, J=5.1 \mathrm{~Hz}) ; 7.56(2 \mathrm{H}, \mathrm{t}, J=$ $5.7 \mathrm{~Hz}) ; 7.44(4 \mathrm{H}, \mathrm{d}, J=4.0 \mathrm{~Hz}) ; 4.52(4 \mathrm{H}, \mathrm{s})$ (see Supplementary Information).

\subsection{Synthesis of bi-copper(II)-bisacetato- $\mu$-phthalicacid[bis(benzyloxy) ethyl]ester ( ( $\left.\left.\mathrm{CH}_{3} \mathrm{COO}\right) \mathrm{Cu}(\mathrm{II}) \mathrm{LCu}(\mathrm{II})\left(\mathrm{OOCCH}_{3}\right)\right), \mathrm{Cu}_{2} \mathrm{C}_{22} \mathrm{H}_{20} \mathrm{O}_{12}$}

$\mathrm{Cu}(\mathrm{II})$ acetate monohydrate $1 \mathrm{mmol}(0.199 \mathrm{~g})$ was dissolved in $10 \mathrm{~mL}$ methanol. A solution of $\mathrm{L}$, prepared by dissolving $1 \mathrm{mmol}(0.380 \mathrm{~g})$ into $10 \mathrm{~mL}$ of methanol, was added dropwise with vigorous stirring. The stirring was continued for three hours till dark blue precipitate was obtained. The precipitate was washed with diethyl ether and dried in air. The compound was recrystallized from acetonitrile to get blue coloured crystals.

\section{Results and Discussion}

\subsection{Electronic and vibrational spectroscopy of $\left(\mathrm{CH}_{3} \mathrm{COO}\right) \mathrm{Cu}(\mathrm{II}) \mathrm{LCu}(\mathrm{II})\left(\mathrm{OOCCH}_{3}\right)$}

The UV/visible spectra of the complex was recorded in acetonitrile and a broad band was observed at $\lambda_{\max }$ $714 \mathrm{~nm}$ (figure 1). The extinction coefficient $(\varepsilon)$ was calculated to be $709.68 \mathrm{~L} \mathrm{~mol}^{-1} \mathrm{~cm}^{-1}$.

Vibrational spectra for the complex synthesized showed peaks at $2966.5 \mathrm{~cm}^{-1}\left(v_{\mathrm{C}-\mathrm{H}}\right.$ of $\left.\mathrm{C}_{6} \mathrm{H}_{5}\right) ; 756$ $\mathrm{cm}^{-1} \& 705 \mathrm{~cm}^{-1}$ (C-H out of plan vibration for $\mathrm{C}_{6} \mathrm{H}_{5}$ ); $1631.7 \mathrm{~cm}^{-1}\left(v_{\mathrm{C}=\mathrm{O}}\right) ; 1400 \mathrm{~cm}^{-1}\left(v_{\mathrm{symm}} . \mathrm{COO}^{-}\right) ; 1589.3$ $\mathrm{cm}^{-1}\left(v_{\text {asymm }} \cdot \mathrm{COO}^{-}\right) ; 3441 \mathrm{~cm}^{-1}\left(v_{\mathrm{O}-\mathrm{H}}\right)$.

\subsection{EPR spectroscopy of $\left(\mathrm{CH}_{3} \mathrm{COO}\right) \mathrm{Cu}(\mathrm{II}) \mathrm{LCu}(\mathrm{II})$ $\left(\mathrm{OOCCH}_{3}\right)$}

The X-band EPR spectra of the complex was recorded as the polycrystalline samples at room temperature (figure 2). The $\mathrm{g}_{\text {iso }}$ value and geometric parameter $\mathrm{G}$ i.e.,

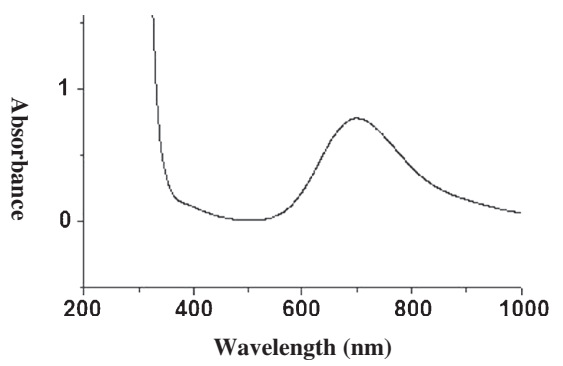

Figure 1. The UV/visible spectrum of $\left(\mathrm{CH}_{3} \mathrm{COO}\right) \mathrm{Cu}$ (II) $\mathrm{LCu}(\mathrm{II})\left(\mathrm{OOCCH}_{3}\right)$ in acetonitrile. $\left(1 \times 10^{-3} \mathrm{M}\right.$, path length $1.0 \mathrm{~cm}$ ) 


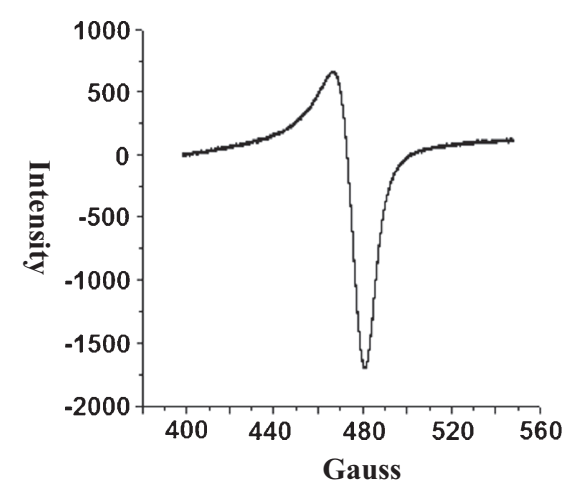

Figure 2. The $\mathrm{X}$-band EPR spectra of $\left(\mathrm{CH}_{3} \mathrm{COO}\right) \mathrm{Cu}(\mathrm{II})$ $\mathrm{LCu}(\mathrm{II})\left(\mathrm{OOCCH}_{3}\right)$ recorded as the polycrystalline samples at room temperature.

the measurement of exchange interaction between the copper centres was evaluated by using the expression: ${ }^{31}$

$$
\begin{gathered}
\mathrm{g}_{\text {iso }}=1 / 3\left(g_{\|}+2 g_{\perp}\right) \\
\mathrm{G}=\frac{\left(g_{\|}-2.0023\right)}{\left(g_{\perp}-2.0023\right)}=\frac{4 K_{\|} 2 \Delta E_{x z}}{k_{\perp}^{2} \Delta E_{x y}}
\end{gathered}
$$

The calculated value of $\mathrm{g}$ tensor parameter was $\mathrm{g}_{\|}=$ 2.06 and $g_{-}=2.03$. Hence, $g_{\|} g_{-}>2.003$ which reveals that $d_{x^{2}-y^{2}}$ is the ground state. ${ }^{32}$ The value of $G$ was calculated to be 2.04 which is less than 4 indicating effective interaction between the copper centres. ${ }^{33}$

\subsection{Magnetic moment of $\left(\mathrm{CH}_{3} \mathrm{COO}\right) \mathrm{Cu}(\mathrm{II}) \mathrm{LCu}(\mathrm{II})$ $\left(\mathrm{OOCCH}_{3}\right)$}

The magnetic moment value was measured to be 1.65 $\mathrm{BM}$ which is a little lower than the single electron value of $1.74 \mathrm{BM}$. This low value of magnetic moment may be due to anti-ferromagnetic coupling of the individual magnetic moments of the copper (II) centres.

\subsection{Thermogravimetric studies of $\left(\mathrm{CH}_{3} \mathrm{COO}\right) \mathrm{Cu}(\mathrm{II})$ $\mathrm{LCu}(\mathrm{II})\left(\mathrm{OOCCH}_{3}\right)$}

Thermogravimetric weight loss curve for the complex is shown in figure 3. The weight loss profile as a

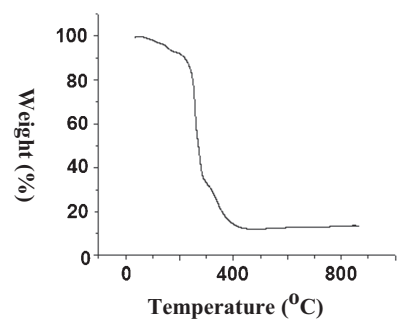

Figure 3. TGA curve of $\left(\mathrm{CH}_{3} \mathrm{COO}\right) \mathrm{Cu}(\mathrm{II}) \mathrm{LCu}(\mathrm{II})(\mathrm{OOC}$ $\left.\mathrm{CH}_{3}\right)$.

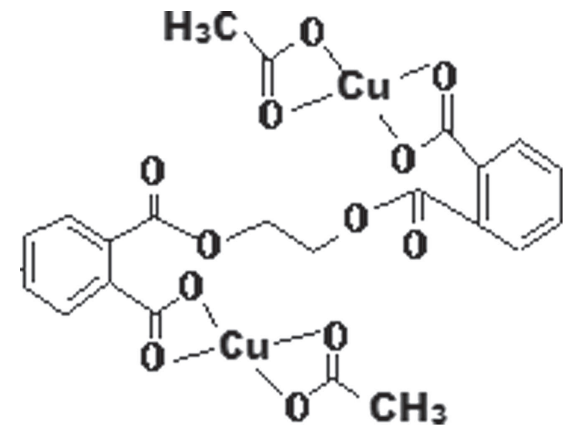

Scheme 2. Proposed structure of $\left(\mathrm{CH}_{3} \mathrm{COO}\right) \mathrm{Cu}$ (II)LCu(II) $\left(\mathrm{OOCCH}_{3}\right)$, confirmed by DFT calculation (figure 5).

function of temperature showed one step at ca. $210^{\circ} \mathrm{C}$ with a shoulder at $310^{\circ} \mathrm{C}$. It is well known that acetates dissociate in the temperature range $200^{\circ} \mathrm{C}$ to $400^{\circ} \mathrm{C}$. The weight loss profile has been analysed as reported in literature. ${ }^{34}$ The total loss in weight is ca. $73.61 \%$. This weight loss is justified if we assume that the end product is two equivalent of $\mathrm{CuO}$. This thermogravimetric analysis supports the structure of the complex as depicted in scheme 2.

\subsection{ESI-MS of $\left(\mathrm{CH}_{3} \mathrm{COO}\right) \mathrm{Cu}(\mathrm{II}) \mathrm{LCu}(\mathrm{II})\left(\mathrm{OOCCH}_{3}\right)$}

The ESI-MS spectra were measured in order to confirm the composition and purity of the compound under investigation. The spectra displayed the molecular ion peak of complex at $\mathrm{m} / \mathrm{z} 602.48$. The calculated value of molecular mass of complex is 603.48 .

\subsection{Electrochemistry of $\left(\mathrm{CH}_{3} \mathrm{COO}\right) \mathrm{Cu}(\mathrm{II}) \mathrm{LCu}(\mathrm{II})$ $\left(\mathrm{OOCCH}_{3}\right)$}

Cyclic voltammogram of $1.0 \mathrm{mM}$ solution of the complex in acetonitrile was done on Pt disc electrode. A very sharp irreversible reduction peak was observed at $-0.005 \mathrm{~V}$ versus $\mathrm{Ag}-\mathrm{AgCl}$ (Scan rate $0.1 \mathrm{Vs}^{-1}$ ). This observation is obvious because in the complex, the $\mathrm{Cu}(\mathrm{II})$ ion is bound to four hard oxygen donor sites which makes the co-ordination very stable. On reduction of $\mathrm{Cu}$ (II) into $\mathrm{Cu}(\mathrm{I})$, which is relatively soft, the four oxygen donors are no longer suitable and the complex is expected to break down. Hence, the irreversible reduction peak without any oxidation counterpart was observed.

\subsection{DFT optimization of the complex}

The complex has been optimized using $6-31+\mathrm{G}(\mathrm{d})$ basis set, with Becke three-parameter exchange and Lee, Yang and Parr correlation functional, B3LYP; ${ }^{35}$ the 


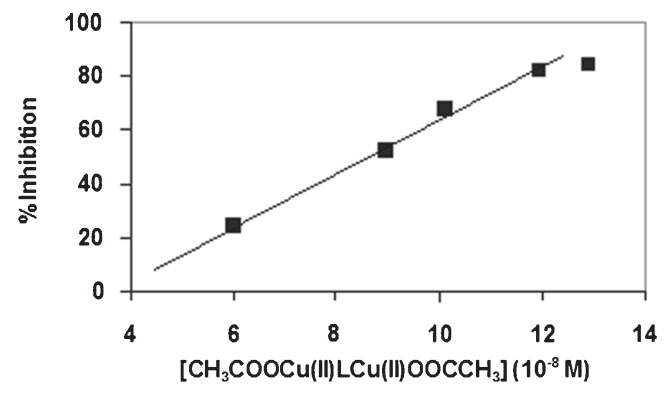

Figure 4. Plot of the percentage inhibition of superoxide formation against the $\left(\mathrm{CH}_{3} \mathrm{COO}\right) \mathrm{Cu}$ (II) $\mathrm{LCu}(\mathrm{II})\left(\mathrm{OOCCH}_{3}\right)$ concentration.

optimized structure is shown in figure 4. The DFT optimised structure shows that each of the two carboxylates of $\mathrm{L}$ binds one $\mathrm{Cu}^{2+}$ ion. Each of the $\mathrm{Cu}^{2+}$ ion is bound to one acetate in a planar mode. The final structure of the complex resembles the alphabet $\mathrm{Z}$.

\subsection{SOD activity of $\left(\mathrm{CH}_{3} \mathrm{COO}\right) \mathrm{Cu}(\mathrm{II}) \mathrm{LCu}(\mathrm{II})$ $\left(\mathrm{OOCCH}_{3}\right)$}

The SOD activity of copper (II) phthalicacid[bis(benzyloxy)ethyl]ester has been studied by the method of nitrobluetetrazolium (NBT, Structure included in SI) reduction using $\mathrm{KO}_{2}^{-}$as the source of superoxide radical. ${ }^{36}$ The blue colour developed due to the formation of formazon dye was measured immediately at $560 \mathrm{~nm}$ against an appropriate blank. One unit of SOD activity $\left(\mathrm{IC}_{50}\right.$ value) was defined as the amount of test substance required for $50 \%$ inhibition of NBT reduction by the superoxide anion. ${ }^{25}$ A linear relation was obtained between the concentration of the copper complex and the inhibition of the superoxide ion. The $100 \%$ of superoxide activity corresponds to an assay performed in the absence of complex. In order to determine the concentration of the complex required to yield $50 \%$ inhibition of the reaction, we plotted the percentage of inhibition against the metal concentration (figure 4) and the obtained $\mathrm{IC}_{50}$ value was $8.6 \times 10^{-6}$ $\mathrm{M}$ (the $\mathrm{IC}_{50}$ value of the native enzyme is $9.5 \times 10^{-9}$ $\mathrm{M})$. This $\mathrm{IC}_{50}$ value is smaller than many reported ones, for e.g., $\mathrm{IC}_{50}$ values are found in the range $3.0 \times 10^{-5}$ $\mathrm{M}$ to $3.7 \times 10^{-5} \mathrm{M}$ for $\mathrm{Cu}(\mathrm{II})$ complexes of amino acids; ${ }^{37} 9.9 \times 10^{-5} \mathrm{M}$ to $2.4 \times 10^{-4} \mathrm{M}$ for the $\mathrm{Cu}$ (II) complexes with simple dipeptides. ${ }^{38}$ It has been proposed that only complexes with $\mathrm{IC}_{50}$ values below $20 \times 10^{-6} \mathrm{M}$ may become clinically interesting. ${ }^{39}$ Therefore, $\mathrm{LCu}(\mathrm{II})\left(\mu-\mathrm{CH}_{3} \mathrm{COO}\right)_{2} \mathrm{Cu}$ (II) fulfils this requirement and appears to be an interesting possibility for further investigations in the field of SOD-mimetic drugs (figure 5).

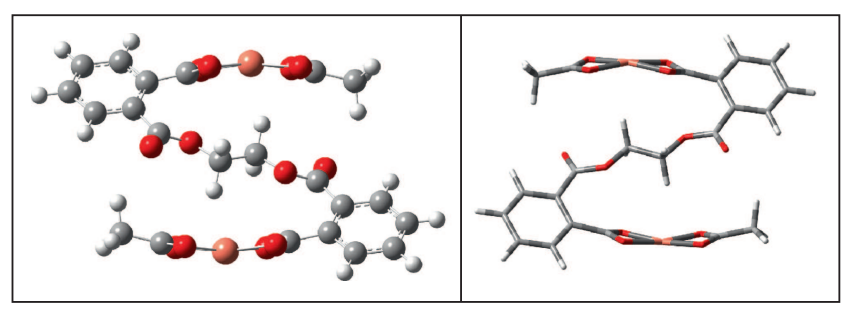

Figure 5. DFT optimized structures of $\left(\mathrm{CH}_{3} \mathrm{COO}\right) \mathrm{Cu}$ (II) $\mathrm{LCu}(\mathrm{II})\left(\mathrm{OOCCH}_{3}\right)$. Pink $=\mathrm{Cu}(\mathrm{II}) ; \mathrm{Red}=\mathrm{O}$; Gray $=\mathrm{C}$; White $=\mathrm{H}$.

\section{Conclusion}

A new binuclear copper(II) complex, $\left(\mathrm{CH}_{3} \mathrm{COO}\right) \mathrm{Cu}$ (II) $\mathrm{LCu}(\mathrm{II})\left(\mathrm{OOCCH}_{3}\right)$, where $\mathrm{L}$ is phthalic acid bis(benzyloxy)ethyl ester, has been synthesized and characterized by various spectroscopic methods. DFT calculation showed a Z-type structure for the complex. Good superoxide scavenging behaviour was observed for the complex.

\section{Supplementary Information}

LC-MS and ${ }^{1}$ HNMR spectra of the ligand $\mathbf{L}$, FTIR and LC-LS spectra of $\left(\mathrm{CH}_{3} \mathrm{COO}\right) \mathrm{Cu}$ (II) $\mathrm{LCu}$ (II) $\left(\mathrm{OOCCH}_{3}\right)$, structure of NBT (Nitrobluetetrazolium) are available at www.ias.ac.in/chemsci.

\section{Acknowledgement}

We thank UGC, New Delhi and DST, New Delhi for financial assistance. BS thanks UGC for fellowship under RFSMS. We thank IIT-Guwahati for ESR and LC-MS spectra.

\section{References}

1. Berdanier C D, Goff J L and Gropper S S 1999 In Advanced Nutrition and Human Metabolism $3^{\text {rd }}$ edition (Belmont: Words Worth/Thompson Learning)

2. Brill A S, Martin R B and Williams R J P 1964 In Electronic Aspects of Biochemistry (New York: Academic Press Inc.)

3. Frieden E, Osaki S and Kobayashi H 1965 J. Gen. Physiol. 49213

4. Pereira R M S, Andrades N E D, Pauling N, Sawaya A C H F, Eberlin M N, Marcucci M C, Favero G M, Novac E M and Bydlowsaki S P 2007 Molecules 12352

5. Afanasev I B, Ostrskhovitchm E A, Chik E V M, Ibraginova C A and Korkina L G 2001 Biochem. Pharmocol. 6167

6. Mohan M, Gupta N K and Kumar M 1992 Inorg. Chim. Acta 19739 
7. Mandal S K and Nag K 1984 J. Chem. Soc. Dalton. Trans. 2141

8. Coughlin P K and Lipard S J 1981 J. Am. Chem. Soc. 1033228

9. Patel R N 2003 Spectrochim. Acta A 59713

10. Gagne R R, Kreh R P and Dodge J A 1979 J. Am. Chem. Soc. 1016917

11. Solomon E I 1983 Pure Appl. Chem. 551069

12. Patel R N, Singh N, Shukla K K, Gundla V L N and Chauhan U K 2005 Spectrochim. Acta A 612603

13. Chiari A S, Daon P E, Hoffman B M and Ibers J A 2001 Angew. Chem. Intl. Ed. Engl. 40244

14. Swearingen J K and West D X 2001 Trans. Met. Chem. 26252

15. Wilkinson G, Gillard R D and Mc Cleverty J A 1987 In Comprehensive Coordination Chemistry vol. 2 (Oxford: Elsevier)

16. Pederson T C and Aust S D 1973 Biochim. Biophys. Res. Commun. 521071

17. Mizushima Y, Igarshi R, Wermuth C G , Koga N, Kinig H and Metcalf B W 1992 In Medicinal Chemistry for the $21^{\text {st }}$ Century (Oxford: Black-well Scientific) p 331

18. Tabbi G, Nauser T, Koppenol W H and Reedijk J 1998 Eur. J. Inorg. Chem. 1939

19. Halliwell B and Gutteridge J M C 1989 In Free Radicals in Biology and Medicine $2^{\text {nd }}$ Edition (Oxford: Clarendon Press)

20. Liczmanski A E, Hartmann H-J and Weser U 1994 Bull. Pol. Acad. Sci. Biol. Sci. 42291

21. Liu A-M, Xiong R-G and You X-Z 1997 Polyhedron 16 119

22. Tabbi G, Driessen W L, Reedijk J, Bonomo R P, Veldman N and Spek A L 1997 Inorg. Chem. 361168

23. Bhirud R G and SrivastavaT S 1990 Inorg. Chim. Acta. 173121
24. Barik A, Mishra B, Kunwar A, Kadam R M, Shen L, Dutta S, Padhye S, Satpati A K, Zhang H-Y and Priyadarshini K I 2007 Euro. J. Med. Chem. 42431

25. Patole J, Dutta S, Padhye S and Sinn E 2001 Inorg. Chim. Acta. 318207

26. Lieb E H 1985 In Density Functional Methods in Physics R M Dreizler and J da Provid`encia (Eds.) (New York: Plenum)

27. Christopher J Cramer 2004 In Essentials of Computational Chemistry: Theories and Models $2^{\text {nd }}$ Ed. (England: John Wiley)

28. Koch W and Holthausen M C 2001 In A Chemist's Guide to Density Functional Theory $2^{\text {nd }} \mathrm{E}^{\mathrm{d} .}$ (New York: Wiley-VCH)

29. Cohen A J, Mori-Sánchez P and Yang W 2012 Chem. Rev. 112289

30. Rajbongshi J, Das D K and Mazumdar S 2010 Electrochim. Acta. $\mathbf{5 5} 4174$

31. Chandra S, Jain D and Sharma A K 2009 Spectrochimica. Acta. Part A 711712

32. Searl J W, Smith R C and Wayrad S J 1959 Proc. Phy. Soc. $\mathbf{7 4} 491$

33. Hathaway B J and Billing D E 1970 Coord. Chem. Rev. 5143

34. Prabhumirashi L S and Khoje B H J 2002 Thermochemica Acta $\mathbf{3 8 3} 109$

35. Becker A D 1993 J. Chem. Phys. 985648

36. Arudi R L, Allen A O and Bieiski 1981 FEBS Lett. 135 265

37. Tótaro R M, Apella M C, Torre M H, Friet E, Viera I, Kremer E and Baran E J 1993 Acta Farm. Bonaerense 1273

38. Facchin G, Torre M H, Kremer E, Piro OE, Castellano E E and Baran E J 2002 J. Inorg. Biochem. 89174

39. Roberts N A and Robinson P A 1985 Br. J. Rheumatol. 24128 